\title{
The use of grey alder Alnus incana by foraging Black Woodpeckers Dryocopus martius during winter
}

\author{
Spillkråkans Dryocopus martius vinteranvändning \\ av gråal Alnus incana för födosök
}

\author{
Christer Olsson
}

Sofiehemsvägen 76A, 907 38, Umeå, Sweden | olssoncito@hotmail.com

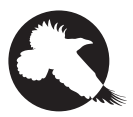

VERY FEW STUDIES have been made on the Black Woodpecker's Dryocopus martius feeding on deciduous trees in Scandinavia, especially at winter. This pilot study on the Black Woodpecker's feeding in grey alder Alnus incana showed that the grey alder is a significant feeding tree during the winter months. The woodpeckers seem to prefer feeding in the southerly sector of grey alder trunks with a diameter of 13.5-15.4 centimetres, in their first dying stages. This study indicates that litter of a significant size, that is found beneath trees penetrated by woodpeckers, are from carvings made by the Black Woodpecker. Litter surveying may hence be an alternative investigational method to radio tracking for nutritional studies on the Black Woodpecker. This paper also discusses the role of a potential prey found in grey alders, the alder wood-wasp Xiphydria camelus, as a complementary food source at winter in different parts of Sweden, compared to the more well-described carpenter ants Camponotus herculeanus found in Norway spruce Picea abies.

Keywords: alder wood-wasp | foraging ecology| riparian forest | winter ecology | Xiphydria camelus

\section{Introduction}

Most European woodpecker species have specialised foraging habits and can only be found in abundance in forests that are not too affected by anthropogenic factors (Cramp 1985, Angelstam \& Mikusiński 1994).
Among them the Black Woodpecker Dryocopus martius is the largest resident woodpecker species in Fennoscandia that exclusively feeds on insects. It forages mostly on ants (Formicidae) and a variety of 
other insects living in dead wood (Cramp 1985). The European breeding population is large, estimated to more than 740,000 pairs (Burfield \& van Bommel 2004). The Swedish population is estimated to 29,000 pairs (Ottosson et al. 2012) and has declined during the last decades. Since 2015 it is listed as Near Threatened in the Swedish Red List (SLU Artdatabanken 2020). It has been suggested that the scarcity of snags in managed forests affects the ability of the Black Woodpecker to survive harsh winter conditions in northern Sweden (Mikusiński 1995).

Compared to other European woodpeckers, the Black Woodpecker is large (body mass 200-350 g) and has a massive bill (Cramp 1985), which allows it to utilize food sources in hard wood that are unavailable to other woodpeckers. The Black Woodpecker can make deep carvings when feeding or preparing nesting holes in coniferous trees, such as Norway spruce Picea abies and Scots pine Pinus silvestris (Johnsson 1993).

Several studies have investigated Black Woodpeckers feeding in stands dominated by coniferous trees, mainly Norway spruce, where carpenter ants Camponotus herculeanus is the bulk food item (Cramp 1985, Haila \& Järvinen 1977, Rolstad \& Rolstad 1995, Mikusiński 1997). This is an abundant and energy-rich food source for woodpeckers, found in snags and basal parts of live spruce trees. It is reasonable to assume that carpenter ants are a main energy source for Black Woodpeckers in most of their Scandinavian range. However, very little attention has been paid to the Black Woodpecker's utilization of deciduous trees as a feeding substrate. One reason for this might be that deciduous trees occur in low abundance in managed forests and therefore are of less importance as feeding substrate, however implying that the relatively few that remain are of more importance.

The feeding of the Middle Spotted Woodpecker Dendrocoptes medius in a contiguous alder forest tract in Brandenburg, NE Germany, was surveyed in a major study (Weiss 2003), showing that areas without trees of $>21 \mathrm{~cm}$ diameter at breast height $(\mathrm{DBH})$ were avoided by the woodpeckers. Forest tracts with standing snags of $>35 \mathrm{~cm} \mathrm{DBH}$ were clearly preferred by the Middle Spotted Woodpecker. The feeding of the White-backed Woodpecker Dendrocopos leucotos, a relatively largesized and strong-billed Fennoscandian woodpecker species, relying almost entirely on trunk-living insects in deciduous trees, was studied in central Sweden (Aulén 1988). The results suggest that silver birch Betula pendula, downy birch B. pubescens, Eurasian aspen Populus tremula, goat willow (great sallow) Salix caprea, European oak Quercus robur, common alder Alnus glutinosa, and grey alder Alnus incana are of importance for feeding White-backed Woodpeckers. Among these deciduous trees, the grey alder is abundant in the areas of this study, the province of Västerbotten, with proximity to the Gulf of Bothnia. When this study was carried out, in 2007, it seemed likely that the Whitebacked Woodpecker was extinct from all of northern Sweden. However, when the species still was found in small numbers in Västerbotten, Olsson \& Wiklund (1999) indicated that grey alder is significant for its energy supply at winter.

My primary hypothesis in this study was that the grey alder could be a significant alternative to Norway spruce for feeding Black Woodpeckers at winter in northern Sweden. The grey alder is an abundant tree associated with both fresh and salty waters in coastal forests in Västerbotten. Large-sized, decaying grey alders are a potential winter-food substrate, because alders are locally common and potential prey insects can be found throughout the trunk.

An important objective of the study was to analyse the composition and abundance of potential prey, specifically the abundant alder wood-wasp Xiphydria camelus, and the characteristics of grey alders used by feeding Black Woodpeckers. In the province of Västerbotten the common alder appears very scarce, but the grey alder is a characteristic tree in its typical habitats. It is even considered a pioneering species in isostatic landscapes.

In addition, I wanted to address whether there exists a relationship between increasing feeding activity in grey alder and decreasing temperature and/or increasing snow depth. Very little research on woodpecker feeding has been based on carving remains. This is therefore a pilot study to test a complementary method to field observation of feeding woodpeckers, which requires lots of time, radio tracking of several birds, and movements over long time spans. Similar studies could be made on the Black Woodpeckers' use of Norway spruce, Scots pine, birches and goat willow. 


\section{Material and methods}

\section{IDENTIFICATION OF WOOD LITTER FROM WOODPECKER FORAGING}

Because of a much more powerful bill, the Black Woodpecker produces debris of a significantly larger size than other woodpeckers. Many years of field studies have made me aware of there being a significant difference in size between the debris from a carving in a grey alder of the same decaying stage made by Black Woodpecker and by Three-toed Woodpecker Picoides tridactylus. It is much more difficult to confidently assess whether carvings have been made by Black or White-backed Woodpecker, but at the period of the initial studies in 2004-2005, the White-backed Woodpecker was extinct in the province of Västerbotten. Grey-headed Woodpecker Picus canus and Lesser Spotted Woodpecker Dryobates minor are less challenging, because they produce clearly smaller-sized litter than the Three-toed Woodpecker (personal observations).

In my experience, the risk for misidentification of litter is confined to cases when a Black Woodpecker has quickly abandoned a tree and left only small amounts of debris on the ground. In those instances, it can be difficult to tell apart from that of Three-toed Woodpecker, but by excluding such ambiguous instances I have erred on the side of caution. To quantify debris size, I searched for an area where several species of woodpeckers co-occurred in the same grey alder stand. Close to Holmsund, approximately $15 \mathrm{~km}$ south of Umeå, on 4 November 2004, both Grey-headed, Three-toed, Lesser Spotted and Black Woodpeckers were observed feeding in a 1-ha large grey alder stand. For the Lesser
Spotted Woodpecker, no piece of litter was longer than $12 \mathrm{~mm}$, for the Three-toed Woodpecker litter size did not exceed $23 \mathrm{~mm}$ and for the Black Woodpecker most litter was in the range $4-80 \mathrm{~mm}$. From these observations one can conclude that there is a significant differentiation in size of grey alder litter produced by the different woodpecker species. Beneath alders visited by Grey-headed Woodpeckers I could not find any litter from hard wood at all, just bark that had been removed

\section{STUDY AREA}

The main study was then carried out in an area in the south coastal part of the province of Västerbotten in northern Sweden, where I had previously identified four established Black Woodpecker home ranges through surveys from 1985 and onwards (Table 1).

\section{FIELD METHODOLOGY}

Line surveys of Black Woodpecker feeding activity

Each home range was monitored by walking a fixed route covering $1.5 \mathrm{~km}$ (in total $6 \mathrm{~km}$ ) each Monday morning from 29 November 2004 to 7 March 2005. Snow depth was recorded on each occasion. Each route was in a habitat seemingly optimal for feeding Black Woodpeckers, with a high proportion of grey alders, the focal tree species of this project (Table 1). While walking, I carefully searched for new woodpecker carvings in grey alder. Roughly estimated, 20 ha were covered by each route.

Each route was in areas with contiguous stands of grey alder, which were clearly delineated against other habitat types (e.g., open riverine habitats or

TABLE 1. Characteristics of the four Black Woodpecker Dryocopus martius home range areas that made up the study area. - Egenskaper för de fyra revirområdena för spillkråkor Dryocopus martius som utgjorde studieområdet.

\begin{tabular}{|c|c|c|c|}
\hline $\begin{array}{l}\text { Name } \\
\text { Namn }\end{array}$ & $\begin{array}{l}\text { Location } \\
\text { Plats }\end{array}$ & $\begin{array}{l}\text { Area (ha) } \\
\text { Yta (hektar) }\end{array}$ & $\begin{array}{l}\text { Dominating tree species } \\
\text { Dominerande trädarter }\end{array}$ \\
\hline Hedmansgrundet & $\begin{array}{l}63^{\circ} 44^{\prime} 54.1 " \mathrm{~N} \\
20^{\circ} 20^{\prime} 01.4^{\prime \prime} \mathrm{E}\end{array}$ & 8.1 & $\begin{array}{l}\text { Grey alder Alnus incana, Norway spruce Picea abies, goat } \\
\text { willow Salix caprea, rowan Sorbus aucuparia } \\
\text { Gråal, gran, sälg, rönn }\end{array}$ \\
\hline Tavelån, Tavlefjärden & $\begin{array}{l}63^{\circ} 46^{\prime} 55.7^{\prime \prime} \mathrm{N} \\
20^{\circ} 24^{\prime} 59.3^{\prime \prime} \mathrm{E}\end{array}$ & 8.1 & $\begin{array}{l}\text { Grey alder, goat willow, downy birch Betula pubescens, } \\
\text { Norway spruce } \\
\text { Gråal, sälg, glasbjörk, gran }\end{array}$ \\
\hline Rovsundet & $\begin{array}{l}63^{\circ} 45^{\prime} 04.7^{\prime \prime} \mathrm{N} \\
20^{\circ} 32^{\prime} 21.4^{\prime \prime} \mathrm{E}\end{array}$ & 7.3 & $\begin{array}{l}\text { Grey alder, Norway spruce, rowan } \\
\text { Gråal, gran, rönn }\end{array}$ \\
\hline Tidesviken, Sävarån & $\begin{array}{l}63^{\circ} 52^{\prime} 21.6^{\prime \prime} \mathrm{N} \\
20^{\circ} 33^{\prime} 31.1 " \mathrm{E}\end{array}$ & 8.9 & $\begin{array}{l}\text { Grey alder, goat willow, downy birch, Norway spruce } \\
\text { Gråal, sälg, glasbjörk, gran }\end{array}$ \\
\hline
\end{tabular}


stands dominated by coniferous trees). Approximately 50-100 meters on both sides of the walking path, depending on the density of trees, were scrutinized for woodpecker marks. Trees with new markings were examined carefully to assess whether they were made by a Black Woodpecker or by other woodpecker species, or if the carving was of another origin (e.g., by human activity, wind, or other animals). A recently made carving by Black Woodpecker catches the eye by its cavity hole entrance size, shape, and presence of large woody debris on the ground, and clearly visible amounts of yellowish wood at the entrance hole. Only carvings made in hardwood grey alders were included in this study.

Typical carvings of Black Woodpecker were marked with red spray paint, the tree was tagged with a number attached to a steel wire, and all the litter found beneath the tree was collected and put in a numbered plastic bag. For each feeding tree the following data were recorded: DBH; life stage (based on visual inspection of the branches and the crown, and by putting a slight pressure with a car key in exposed parts of the trunk with no covering bark, to determine whether the wood was penetrable); traces of older woodpecker activity; and abundance of visible insect trails in the bare carving. Furthermore, the height of the carving was measured, and the orientation of the carving was assessed with a compass. I also measured the distance to the closest tree.

\section{Presence of wood-living insects}

Collection of litter was made meticulously, as not to lose smaller dust hidden in the snow or on the ground. An area of at least $20 \mathrm{~m}^{2}$ around each tree was scrutinized for litter. In a few cases, when there were many carvings, I had to return to continue the collection the following day. The litter samples were examined in a laboratory to find out whether there were invertebrate larvae or imagoes of insects remaining. I also examined the insect trails in the samples, because they sometimes can reveal what kind of insects that have caused them (Ehnström \& Axelsson 2002). One of the insects that one is most likely to find in dying but still hard-wooded grey alders is the alder wood-wasp (Roger Pettersson, pers. comm.), which leaves characteristic patterns in the infested wood, with very regular trails of 3-4 $\mathrm{mm}$ diameter (Ehnström \& Axelsson 2002). Even if one does not find any imagoes or larvae, one can say with a high degree of certainty whether the alder wood-wasp has been present, because its larvae live in symbiosis with fungi of the genus Daldinia, whose spores dye the walls of the trails black. The blacker the walls are, the more of the infecting fungus there is. These traces of Daldinia are diagnostic for the presence of the alder wood-wasp (Ehnström \& Axelsson 2002).

Litter samples were brought in cotton bags to the laboratory to dry up and to extract hatched imagoes. The collected litter and two pieces of $50-\mathrm{cm}$ trunk samples from each area were stored in a box in the laboratory and checked twice a week for as long as imagoes hatched (up to three weeks). This was done in order to find out what kind of insects that incubated in the trees recently used by Black Woodpeckers. After two to three weeks, I placed the litter samples into aluminium boxes in a heat chamber, after which I recorded their dry weight.

\section{Quantification of alder stands in Black Woodpecker home ranges}

Eight transect areas were surveyed, i.e., two per investigated home range. The locations of the transects, each $400 \mathrm{~m}^{2}$ large (100 meters long with a width of 40 meters), were randomly designated in areas where grey alders were abundant within each home range. In this choice no consideration was given to tree size, age, or other parameters. The diameter of all the grey alder trunks was measured at breast height.

\section{Weather}

I measured the snow depth in ten randomly selected points along the transect in the survey areas each Monday and recorded the daily temperature at Umeå airport $\left(63^{\circ} 47^{\prime} 30^{\prime \prime} \mathrm{N}, 20^{\circ} 17^{\prime} \mathrm{Oo} " \mathrm{E}\right)$ at 13.00 during the whole study period.

\section{Statistical analyses}

Statistical analyses were performed in Microsoft Excel, including the use of the Data Analysis Toolpak.

\section{Results}

During the 14 weeks of line surveys, a total number of 56 grey alders were found to have been visited by feeding Black Woodpeckers in the four areas (Appendix 1). 


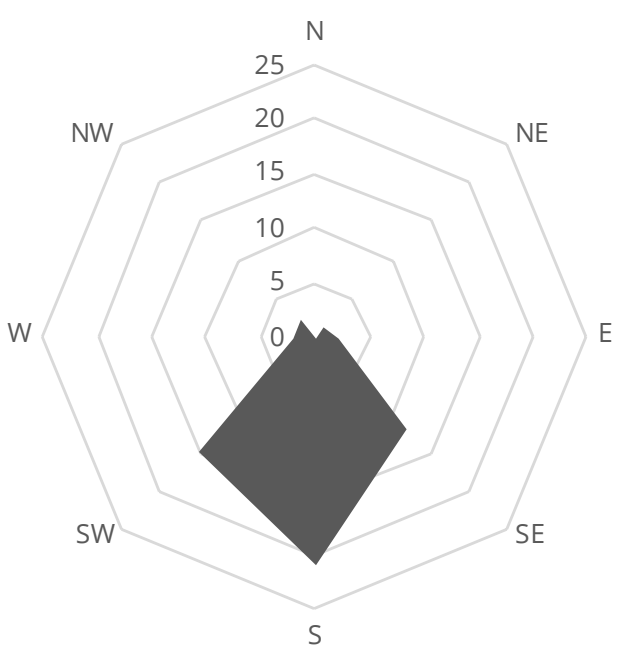

FIGURE 1. Compass rose diagram illustrating the location of Black Woodpecker Dryocopus martius feeding marks on the southerly sector of grey alder Alnus incana trunks. The thin lines indicate increments of five feeding marks, and the dark surface represents all feeding marks, with for example 21 facing south and 15 southwest. For the full data, see Appendix 1.

- Kompassrosdiagram som illustrerar spillkråkans Dryocopus martius placering av födosökshål på södra sektorn av gråalsstammar Alnus incana. De tunna linjerna motsvarar intervall om fem födosökshål och den mörka ytan motsvarar samtliga födosökshål, t.ex. 21 i sydlig och 15 i sydvästlig riktning. För fullständig redogörelse av data, se Appendix 1 .

Out of 56 studied trees, 41 were found in a non-exposed position, with lots of covering trees around it, at a distance of at least 10 meters up to at least 180 degrees. Feeding marks were on average $75 \mathrm{~cm}$ high (standard deviation $[\mathrm{SD}]=67 \mathrm{~cm}$; range $10 \mathrm{~cm}-2.95 \mathrm{~m}$ ), situated with the lower edge on average $3.96 \mathrm{~m}$ over the snow cover $(\mathrm{SD}=2.5 \mathrm{~m}$; range $0.35-9.55 \mathrm{~m} ; \mathrm{n}=63$ feeding marks on the 56 trees; Appendix 1). The feeding marks had a strong directional bias and were found in the southerly sector of the trees (Figure 1; Appendix 1).

Each week, litter from Black Woodpecker carvings of between 1 and 16 grey alders were collected, with an average dry weight per tree of $143.5 \mathrm{~g}$ (Appendix 2). In a limited range of the Rovsundet area 16 trees were intensively carved by Black Woodpeckers between 10 and 17 February 2005. Unfortunately, an early spring flood that week, followed by some cold nights, caused the majority of the grey alder litter from woodpeckers feeding to freeze firmly into the ice that covered an area exceeding 1 ha. For practical reasons it was impossible to retrieve all litter, but examining the size of the carvings compared with the weight of earlier litter collects, gives a rough estimation of $2.0-3.0 \mathrm{~kg}$ for that week, corresponding to $125-187.5 \mathrm{~g}$ per tree (Appendix 2).

For most of the 15 survey occasions, the snow cover was under the average regional level for the season: on ten visits $0-13 \mathrm{~cm}$ and on five visits $28-40 \mathrm{~cm}$, compared to a normal average snow depth of $30-50 \mathrm{~cm}$ (Raab \& Vedin 1995). Neither temperature (linear regression, $t=0.63, F_{1,12}=0.40, r^{2}=0.03, p=0.54$; Figure $2 \mathrm{a})$ or snow depth $\left(\mathrm{t}=0.32, \mathrm{~F}_{1,12}=0.10, \mathrm{r}^{2}=0.01\right.$, $\mathrm{p}=0.75$; Figure $2 \mathrm{~b}$ ) predicted feeding activity in the grey alders, as measured by litter dry weight (Appendix 2).

In the transect study 474 grey alders were classified as being in living stages, among which five $(1.1 \%)$ bore carvings made by Black Woodpeckers during the winter of the study, and six (1.3\%) bore similar carvings from previous years. Another 359 grey alders were classified as being in dying/dead stages with hard wood, among which 37 (10.3\%) bore Black Woodpeckers carvings made during the winter of the study and 119 $(33.1 \%)$ since previous years. If the last measurement is typical for optimal areas with grey alder, it implies that 1,480 suitable trees of this species in dead/dying stages are available for feeding Black Woodpeckers. Furthermore, this means that 324 grey alders per hectare can be used during one single winter by a feeding Black Woodpecker.

\section{Discussion}

This seems to be the first study where the quantification of woodpecker foraging at winter has been made with focus on the grey alder. I conclude that this tree species, where it is abundant, can be a very significant feeding tree during winter for Black Woodpeckers, predominantly in its dying stages.

I hypothesized that when winter conditions became harsher, Black Woodpeckers would switch from the well-described feeding on basal parts of Norway spruce (Cramp 1985, Haila \& Järvinen 1977, Rolstad \& Rolstad 1995, Mikusiński 1997) to feeding on bare parts of grey alders, where potential prey can be abundant. However, I found no correlation between weather and feeding intensity on grey alder (Figure 2). Instead, the results show that also during the mild winter of $2004 / 2005$, with little snow, Black Woodpeckers spent significant 

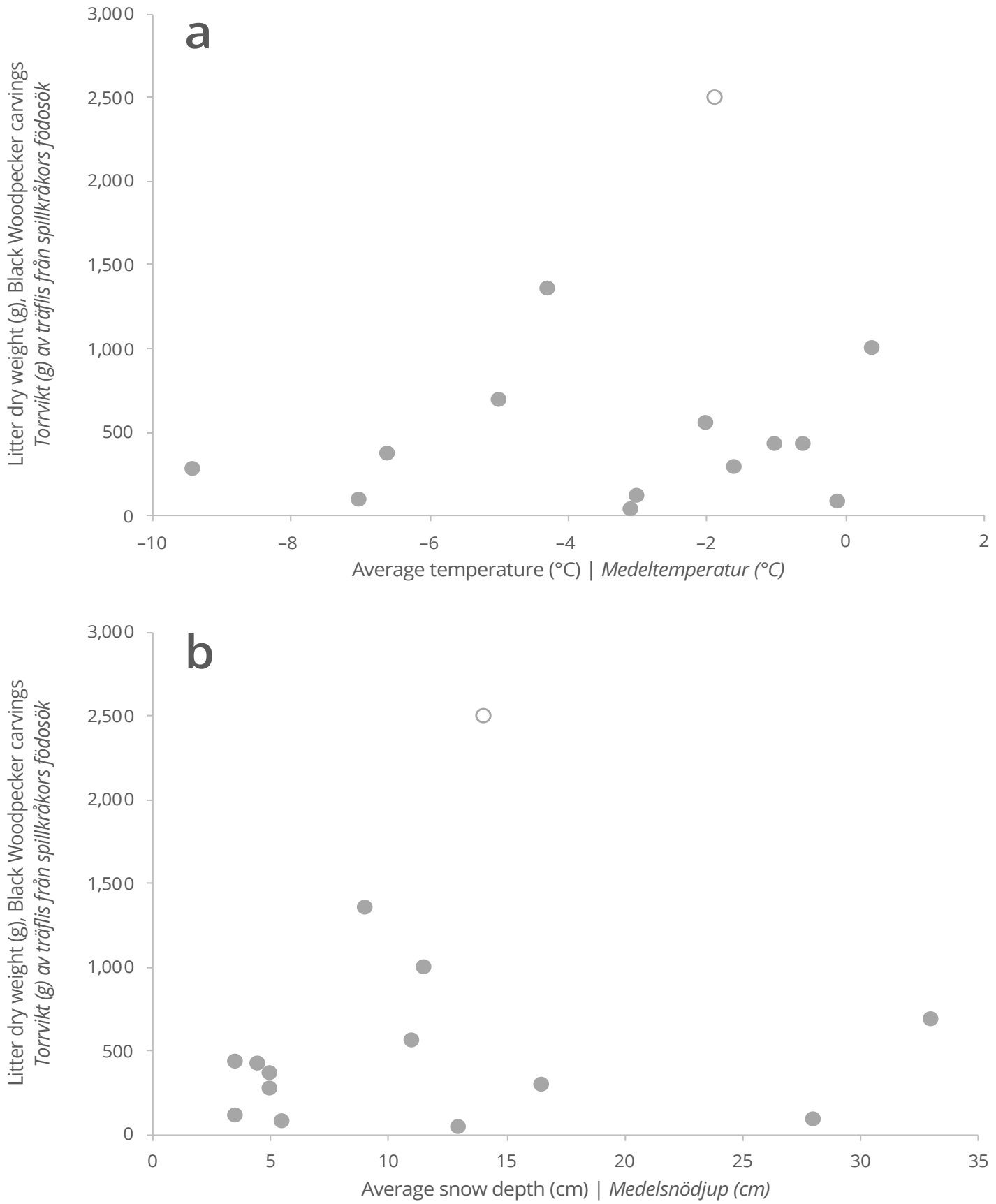

FIGURE 2. The weekly feeding intensity of Black Woodpecker Dryocopus martius, as reflected by the amount of grey alder Alnus incana litter from carvings, shows no correlation with (a) temperature, or (b) snow depth. The hollow datapointpoint corresponds to the week 10-16 January, when the amount of litter could only be estimated to $2-3 \mathrm{~kg}$ (see text), here plotted as $2.5 \mathrm{~kg}$.

- Det finns ingen korrelation mellan spillkråkans Dryocopus martius veckovisa födosöksintensitet, såsom den reflekteras av mängden träflisor av gråal Alnus incana, och (a) temperatur, respektive (b) snödjup. Den ofyllda datapunkten motsvarar veckan 10-16 januari, då flismängden endast kunde uppskattas till $2-3 \mathrm{~kg}$ (se texten), här utritad som 2,5 kg. 
time feeding in grey alders, a poorly described food source. Since the snow cover was under the average during most of the study period, I could not assess the potential effect on feeding by significantly higher snow coverage.

One might argue that this study could not conclusively test the potential effect by snow depth or temperature on the feeding behaviour or Black Woodpeckers, as the winter of 2004/2005 saw less snow and higher temperature than usual. It would therefore be beneficial to repeat this study during another winter with harsh conditions, when the study should also start already before the appearance of the first snow cover and continue until the snow starts to melt. The present study possibly started a little bit too late, as in one study area (Tidesviken) several grey alders had been recently carved by Black Woodpeckers at my first visit on 29 November. I also found at least six grey alders near Tavlefjärden, beneath which was a lot of recent litter from Black Woodpeckers two weeks after finishing this study.

One can speculate about how the Black Woodpeckers cope with the harsh winter climate at northern latitudes, especially when the snow cover is so deep that trunks and snags may be covered. It has been suggested that they have problems to satisfy their daily energy requirements during winter days even in southern and central Scandinavia (Nilsson et al. 1992, Mikusiński 1995), where the climate is less harsh. This begs the question whether Black Woodpeckers in northern Sweden have adapted to other food sources in winter, when their main food source, carpenter ants, may be unavailable or very scarce due to their substrates (stumps and basal parts of spruce trees) being entirely buried in deep snow. It is known that Black Woodpeckers can still access these substrates at a snow depth of $30-40 \mathrm{~cm}$ (Rolstad \& Rolstad 2000), but when the snow depth exceeds one meter-quite normal for many parts of northern Fennoscandia-prey such as wood-wasps in grey alders can be a substitute or complement to carpenter ants. Alder wood-wasps generally deposit their eggs for hatching in the upper parts of grey alders in early decaying stages, when they still are hard-wooded (Ehnström \& Axelsson 2002). These upper parts of the trees are never covered even by the deepest snow (personal observation), implying that Black Woodpeckers can feed on alder wood-wasp larvae also during very snowy winters.

Rolstad \& Rolstad (1995) estimated that a Black Woodpecker in mid-Norway on a midwinter day spends 3-4 hours feeding. In this study, a female Black Woodpecker fed continuously for one hour in the same grey alder tree in the Tavlefjärden study area on 7 March 2005, producing $396 \mathrm{~g}$ (dry weight) of litter. Based on these figures, and if just a single Black Woodpecker was responsible for all litter, it can be estimated that this individual spent approximately $30 \%$ of the total daily feeding time in this limited stand.

Despite widespread occurrence of wood-wasp trails in the grey alder wood, few alder wood-wasps were retrieved from the debris investigated in the laboratory. One explanation can be that the Black Woodpecker is feeding very efficiently, leaving almost no larvae in the litter. Wood-wasp females exclusively oviposits in hard wood of recently decaying grey alders, and the development from egg to adult takes one year up to a couple of years (Ehnström \& Axelsson 2002). I found very few deciduous trees, other than grey alders in their first decaying stages, which could serve as alternative feeding substrates: only some scattered goat willow trees (with some few larger-sized holes that could possibly have been made by a Black Woodpecker) and grey alders in late stages of decay, which were totally damaged by age or weather conditions.

The finding that 41 of 56 studied feeding trees were in non-exposed positions suggests that Black Woodpeckers search for potentially energy-rich grey alder trunks in protective cover from potential flying predators. Ryrholm (1996) showed that in the southernmost part of Sweden some wood-living insects use the full 360 degrees of tree trunks, but in the northernmost part of the country, the insects could only be found in the parts of tree trunks that face southwards, where sunlight increases the temperature. This exposure gradient was corroborated by the findings in this study, that Black Woodpeckers forage almost exclusively on the southerly sector of grey alders (Figure 1).

Areas abundant with grey alders in their earlier decaying stages have a great attraction on feeding Black Woodpeckers, even if the trunks are of a smaller dimension. Decaying grey alders that seem alive to the naked eye are over-represented among trees with carvings 
recently made by Black Woodpeckers. It thus seems as though grey alders only provide wood quality that is optimal for the Black Woodpecker's main insect prey for a few years. This suggests that a specific life stage, rather than a certain trunk diameter, of grey alders is crucial for feeding Black Woodpeckers.

The habitat seems favourable for Black Woodpeckers if stands of grey alders are quite dense. As grey alders are weak competitors with for example Norway spruce, such dense stands are more often found in areas that are regularly flooded by water, which is unfavourable for spruces. Two such terrains are plain areas close to rivers with high altitudinal differences in water level, and areas close to seashores that are exposed to different water levels, both of which are found in the study areas. To maintain a favourable habitat for Black Woodpecker through conservation measures, emerging Norway spruce or pine trees could continuously be manually removed from stands of grey alders.

In the province of Västerbotten, areas in proximity of the Gulf of Bothnia host significant amounts of grey alder, occurring as an important pioneer tree species along coastal uplift areas. The grey alder has a short life cycle, approximately 30 years (cf., e.g., Uri et al. 2014), thereby providing Black Woodpeckers a food resource of relatively short duration. Close to the Gulf of Bothnia, one can find grey alder stands of uniform age, bearing Black Woodpeckers carvings of similarly uniform age, while nearby, younger stands lack any signs of feeding Black Woodpeckers. This indicates that the grey alders need to reach a certain age before they become host trees for insect larvae such as the alder wood-wasp.

From an aspect of conserving important forest landscapes for Black Woodpeckers, I would argue that the grey alder is a significant feeding tree in the study areas. This implies that the north Swedish grey alder habitats described here ought to be protected for the good of the Black Woodpecker-a species classified as Near Threatened in the Swedish Red List of threatened species (SLU Artdatabanken 2020).

\section{Acknowledgements}

Many thanks to Lars Edenius, SLU, Umeå, who has been my scientific guide over the years through this entire project. Many thanks also to Roger Pettersson, SLU, Umeå, for letting me take part of his great knowledge of insects to be found in trunks of grey alders. I thank two anonymous reviewers for constructive comments on a previous version of this manuscript.

\section{References}

Angelstam P \& Mikusiński G. 1994. Woodpecker assemblages in natural and managed boreal and hemiboreal forest-a review. Annales Zoologi Fennici 31: 157-172. Available at http://www.sekj. org/PDF/anzf $31 /$ anz31-157-172.pdf

Aulén G. 1988. Ecology and distribution history of the White-backed Woodpecker Dendrocopos leucotos in Sweden. PhD thesis, Swedish University of Agricultural Sciences, Uppsala.

Brotons L, Mönkkönen M, Huhta E, Nikula A \& Rajasärkkä A. 2003. Effects of landscape structure and forest reserve location on oldgrowth forest bird species in Northern Finland. Landscape Ecology 18: 377-393. https://doi.org/10.1023/A:1026148825138

Burfield I \& van Bommel F (eds). 2004. Birds in Europe: population estimates, trends and conservation status. BirdLife Conservation Series no. 12. BirdLife International, Cambridge, UK.

Bütler R, Angelstam P, Ekelund P \& Schlaepfer R. 2004. Dead wood threshold values for the three-toed woodpecker presence in boreal and sub-Alpine forest. Biological Conservation 119: 305-318. https://doi.org/10.1016/j.biocon.2003.11.014

Cramp S (ed). 1985. Handbook of the Birds in Europe, the Middle East and North Africa: The Birds of the Western Palearctic, Vol. IV. Oxford University Press, Oxford.

Carlsson, A. 200o. The effect of habitat loss on a deciduous forest specialist species: the White-backed Woodpecker (Dendrocopos leucotos). Forest Ecology and Management 131: 215-221. https://doi.org/10.1016/S0378-1127(99)00215-7

Ehnström B \& Axelsson R. 20o2. Insektsgnag i bark och ved. Artdatabanken, Swedish University of Agricultural Sciences, Uppsala, Sweden.

Fernandez C \& Azkona P. 1996. Influence of forest structure on the density and distribution of the White-backed Woodpecker Dendrocopos leucotos and Black Woodpecker Dryocopus martius in Quinto Real (Spanish western Pyrenees). Bird Study 43: 305-313. https://doi.org/10.1080/00063659609461023

Gunn J \& Hagan JM III. 2ooo. Woodpecker abundance and tree use in uneven-aged managed, and unmanaged, forest in northern Maine. Forest Ecology and Management 126: 1-12. https://doi.org/10.1016/S0378-1127(99)ooo78-X

Haila Y \& Järvinen O. 1977. Competition and habitat selection in two large woodpeckers. Ornis Fennica 54: 73-78. Available at https:// tinyurl.com/yabqdqtd

Hogstad O. 1991. The effect of social dominance on foraging by the Three-toed Woodpecker Picoides tridactylus. Ibis 133: 271-276. https://doi.org/10.1111/j.1474-919X.1991.tbo4569.x

Imbeau L, Mönkkönen M \& Desrochers A. 2001. Long-term effects of forestry on birds of the eastern Canadian boreal forests: a comparison with Fennoscandia. Conservation Biology 15: 1151-1162. https://doi.org/10.1046/j.1523-1739.2001.0150041151.x

Imbeau L \& Desrochers A. 2002. Area sensitivity and edge avoidance: the case of the Three-toed Woodpecker (Picoides tridactylus) in a managed forest. Forest Ecology and Management 164: 249-256. https://doi.org/10.1016/So378-1127(01)00598-9

Johannesson H, Læssøe T \& Stenlid J. 2ooo. Molecular and morphological investigation of Daldinia in northern Europe. Mycological Research 104: 275-280. https://doi.org/10.1017/S0953756299001719 
Johansson T. 1999. Dry matter amounts and increment in 21- to 91-year-old common alder and grey alder and some practical implications. Canadian Journal of Forest Research 29: 1679-1690. https://doi.org/10.1139/x99-126

Johnsson K. 1993. The Black Woodpecker Dryocopus martius as a keystone species in forest. $\mathrm{PhD}$ thesis, Swedish University of Agricultural Sciences, Uppsala.

Kärki T, Maltamo M \& Eerikäinen K. 20oo. Diameter distribution, stem volume and stem quality models for grey alder (Alnus incana) in eastern Finland. New Forests 20: 65-86. https://doi. org/10.1023/A:1006793616781

Liknes ET \& Swanson DL. 1996. Seasonal variation in cold tolerance, basal metabolic rate, and maximal capacity for thermogenesis in White-breasted Nuthatches Sitta carolinensis and Downy Woodpeckers Picoides pubescens, two unrelated arboreal temperate residents. Journal of Avian Biology 27: 279-288. https://doi. org/10.2307/3677259

Matthysen E, Cimprich D \& Grubb TC Jr. 1993. Home ranges and social behaviour of the Downy Woodpecker Picoides pubescens in winter. Belgian Journal of Zoology 123: 193-201. Available at https:// tinyurl.com/y9y8c2ze.

Melletti M \& Penteriani V. 2003. Nesting and feeding tree selection in the endangered White-backed Woodpecker, Dendrocopos leucotos lilfordi. The Wilson Bulletin 115: 299-306. https://doi. org/10.1676/03-022

Mikusiński G. 1995. Population trends in black woodpecker in relation to changes and characteristics of European forests. Ecography 18: 363-369. https://doi.org/10.1111/j.160o-0587.1995.tboo139.x

Mikusiński G. 1997. Winter foraging of the Black Woodpecker Dryocopus martius in managed forest in south-central Sweden. Ornis Fennica 74: 161-166. Available at https://tinyurl.com/y8wa6rjq.
Mikusiński G. 1997. Woodpeckers in Time and Space. PhD thesis, Swedish University of Agricultural Sciences, Uppsala.

Nilsson SG, Olsson O, Svensson S \& Wiktander U. 1992. Population trends and fluctuations in Swedish woodpeckers. Ornis Svecica 2: 13-21. https://doi.org/10.34080/os.v2.22398

Olsson C \& Wiklund J. 1999. Västerbottens fåglar. Västerbottens Ornitologiska Förening, Umeå.

Ottosson U, Ottvall R, Elmberg J, Green M, Gustafsson R, Haas F, Holmqvist N, Lindström $\AA$, Nilsson L, Svensson M, Svensson S \& Tjernberg M. 2012. Fåglarna i Sverige - antal och förekomst. Sveriges Ornitologiska Förening, Halmstad.

Raab B \& Vedin H (eds). 1995. Klimat, sjöar och vattendrag. Sveriges Nationalatlas, band 14. Sveriges Nationalatlas Förlag, Stockholm.

Rolstad J \& Rolstad E. 1995. Seasonal patterns in home range and habitat use of the Grey-headed Woodpecker Picus canus as influenced by the availability of wood. Ornis Fennica 72: 1-13.

Rolstad J \& Rolstad E. 20oo. Influence of large snow depths on Black Woodpecker Dryocopus martius foraging behavior. Ornis Fennica 77: 65-70.

SLU Artdatabanken. 2020. Spillkråka Dryocopus martius. Artfakta. Available at https://artfakta.se/naturvard/taxon/ dryocopus-martius-100049

Uri V, Aosaar J, Varik M, Becker H, Ligi K, Padari A, Kanal A \& Lõhmus K. 2014. The dynamics of biomass production, carbon and nitrogen accumulation in grey alder (Alnus incana (L.) Moench) chronosequence stands in Estonia. Forest Ecology and Management 327: 106-117. https://doi.org/10.1016/j.foreco.2014.04.040.

Weiss, S. 2003. Erlänwälder als bisher unbeachteter Lebensraum des Mittelspechts Dendrocopos medius. Vogelwelt 124: 177-192.

\section{Svensk sammanfattning}

Mycket få undersökningar har gjorts av spillkråkans Dryocopus martius födosök i lövträd, särskilt vintertid. Denna undersökning syftar till att vara en inledande studie av främst spillkråkans födosök vintertid i gråal Alnus incana. Resultaten tyder på att gråalen om vintern är ett viktigt träd för sök av föda för denna hackspett. Totalt hittades 56 gråalar som bar tydliga hackbearbetningar efter spillkråka gjorda under vintern 2004/2005 inom fyra undersökningsområden belägna i Västerbottens södra kustland. I varje område genomsöktes en slinga om ca 1,5 kilometer på fot, placerad i etablerade spillkråkerevir med närmast optimal gråalsförekomst, en gång i veckan från 29 november till 6 mars.

Den transektstudie som gjordes visade att 10,3\% av gråalarna i döende stadium, men alltjämt med hård ved, bar spår av födosökande spillkråkor, gjorda under den aktuella vintern. Om man inkluderar även äldre spår av spillkråkans sök efter föda var totalt $33,1 \%$ av gråalarna i nämnda stadium påverkade i dessa områden. Slår man ut detta på arealnivå innebär det att i optimala gråalsmiljöer för spillkråkan (med gott om nyligen död, hård ved) skulle det kunna finnas 1480 lämpliga födosökträd per hektar. Spillkråkan tycks föredra gråalar med en diameter på mellan 13,5 och $15,4 \mathrm{~cm}$, i det första döendestadiet.

Denna studie visar också att man kan spåra födosök av spillkråka i gråalar genom att mäta längden på de träflisor som hittas under de bearbetade träden. Det är en eftersöksmetod som vanligen är betydligt enklare tillämpbar än att följa radiosändarförsedda spillkråkor.

I denna uppsats diskuteras vidare kamelstekelns Xiphydria camelus betydelse som komplementär födokälla vintertid till den välbeskrivna favoritfödan hästmyror Camponotus herculeanus, som spillkråkan 
hittar i granar Picea abies inte bara i Västerbotten, där de huvudsakliga fältstudierna i denna rapport utförts.

Under vintern 2004/2005, då studien gjordes, var snödjupet under nästan hela perioden långt under det normala och temperaturen över det normala, vilket medförde att granarnas basala delar och av skogsbruket lämnade stubbar inte täcktes av snö. Därför kunde jag inte testa huruvida spillkråkornas användning av gråalar korrelerade med strängare vinterväder.

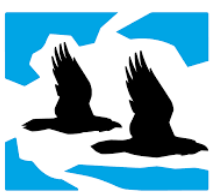

BirdLife Sverige

Ornis Svecica (ISSN 2003-2633) is an open access, peer-reviewed scientific journal published in English and Swedish by BirdLife Sweden. It covers all aspects of ornithology, and welcomes contributions from scientists as well as non-professional ornithologists. Accepted articles are published at no charge to the authors. Read papers or make a submission at os.birdlife.se.

Ornis Svecica (ISSN 2003-2633) är en fritt tillgänglig granskad vetenskaplig tidskrift som ges ut på svenska och engelska av BirdLife Sverige. Den täcker ornitologins alla områden och välkomnar bidrag från såväl forskare som icke-professionella ornitologer. Accepterade uppsatser publiceras utan kostnad för författarna. Läs uppsatser eller skicka in ditt bidrag på os.birdlife.se. 


\section{Appendix 1. Data on individual grey alders Alnus incana foraged by Black Woodpeckers Dryocopus martius}

\begin{tabular}{|c|c|c|c|c|c|}
\hline \multirow{3}{*}{$\begin{array}{l}\text { Area } \\
\text { Område }\end{array}$} & \multicolumn{2}{|c|}{ Tree charachteristics Trädegenskaper } & \multicolumn{3}{|c|}{ Carving charachteristics Hålegenskaper } \\
\hline & $\begin{array}{l}\text { Stem diameter at } \\
\text { breast height }(\mathrm{cm})\end{array}$ & Quality / life stage & $\begin{array}{l}\text { Height above } \\
\text { snow cover }(\mathrm{m})\end{array}$ & Direction & Position \\
\hline & $\begin{array}{l}\text { Stamdiameter vid } \\
\text { brösthöjd }(\mathrm{cm})\end{array}$ & Kvalitet / livsstadium & $\begin{array}{l}\text { Höjd över snö- } \\
\text { täcket }(m)\end{array}$ & Riktning & Position \\
\hline Hedmansgrundet & 15.3 & With canopy & $6.40-7.95$ & SE & Not exposed \\
\hline Tidesviken & 10.7 & With canopy & $\begin{array}{l}1.85-2.65 \\
4.45-5.10\end{array}$ & NW & Exposed \\
\hline Tidesviken & 15.5 & With canopy & $1.50-2.75$ & $\mathrm{~s}$ & Exposed \\
\hline Tidesviken & 9 & Dead trunk & $1.95-4.90$ & SE & Exposed \\
\hline Tavlefjärden & 13.2 & Dead trunk & $3.30-3.59$ & W & Not exposed \\
\hline Tavlefjärden & 14.1 & With canopy & $\begin{array}{l}3.45-4.60 \\
6.30-7.55\end{array}$ & SW & Not exposed \\
\hline Hedmansgrundet & 19.8 & With canopy & $8.70-9.55$ & $\mathrm{~s}$ & Not exposed \\
\hline Hedmansgrundet & 16.1 & With canopy & $6.20-6.65$ & SE & Not exposed \\
\hline Hedmansgrundet & 17.3 & Dead trunk & $7.90-8.20$ & $\mathrm{~s}$ & Not exposed \\
\hline Tavlefjärden & 18.6 & Dead trunk & $1.70-3.25$ & NE & Exposed \\
\hline Tidesviken & 15.5 & With canopy & $1.50-1.70$ & S & Exposed \\
\hline Tidesviken & 15.9 & With canopy & $6.45-6.70$ & SE & Exposed \\
\hline Tidesviken & 9 & With canopy & $1.95-2.05$ & $\mathrm{E}$ & Exposed \\
\hline Tidesviken & 10.7 & With canopy & $2.20-2.50$ & NW & Exposed \\
\hline Tidesviken & 10.9 & Dead trunk & $1.60-3.20$ & $\mathrm{~S}$ & Not exposed \\
\hline Tidesviken & 8.4 & Dead trunk & $0.35-0.90$ & SW & Not exposed \\
\hline Tavlefjärden & 15.3 & With canopy & $\begin{array}{l}\text { 1.85-2.25; } \\
3.25-3.50\end{array}$ & SW & Not exposed \\
\hline Tavlefjärden & 26.8 & With canopy & $8.15-8.45$ & $\mathrm{~s}$ & Exposed \\
\hline Rovsundet & 16.7 & Dead trunk & $5.35-5.60$ & SE & Not exposed \\
\hline Tidesviken & 10.9 & Dead trunk & $1.75-3.25$ & SW & Not exposed \\
\hline Tidesviken & 10.7 & Dead trunk & $1.90-2.25$ & SW & Exposed \\
\hline Rovsundet & 16.7 & With canopy & $6.45-6.80$ & $\mathrm{~s}$ & Not exposed \\
\hline Rovsundet & 14.9 & Dead trunk & $1.15-1.40$ & $\mathrm{~s}$ & Not exposed \\
\hline Rovsundet & 17.2 & With canopy & $5.30-5.90$ & $\mathrm{~s}$ & Not exposed \\
\hline Tavlefjärden & 19.8 & With canopy & $5.70-6.25$ & $\mathrm{~S}$ & Exposed \\
\hline Rovsundet & 11.9 & With canopy & $\begin{array}{l}2.45-3.30 \\
3.90-4.20\end{array}$ & SW & Not exposed \\
\hline Rovsundet & 9.2 & Dead trunk & $0.35-2.60$ & SE & Not exposed \\
\hline Rovsundet & 9.6 & Dead trunk & $2.60-3.15$ & $\mathrm{~s}$ & Not exposed \\
\hline Rovsundet & 10.7 & Dead trunk & $0.65-1.90$ & SW & Not exposed \\
\hline Rovsundet & 13.7 & With canopy & $6.55-7.10$ & SW & Not exposed \\
\hline Rovsundet & 12.9 & Dead trunk & $1.10-2.05$ & $\mathrm{~S}$ & Not exposed \\
\hline Rovsundet & 13.2 & Dead trunk & $1.85-3.10$ & SE & Not exposed \\
\hline
\end{tabular}




\begin{tabular}{|c|c|c|c|c|c|}
\hline \multirow{3}{*}{$\begin{array}{l}\text { Area } \\
\text { Område }\end{array}$} & \multicolumn{2}{|c|}{ Tree charachteristics Trädegenskaper } & \multicolumn{3}{|c|}{ Carving charachteristics Hålegenskaper } \\
\hline & $\begin{array}{l}\text { Stem diameter at } \\
\text { breast height }(\mathrm{cm})\end{array}$ & Quality/life stage & $\begin{array}{l}\text { Height above } \\
\text { snow cover (m) }\end{array}$ & Direction & Position \\
\hline & $\begin{array}{l}\text { Stamdiameter vid } \\
\text { brösthöjd }(\mathrm{cm})\end{array}$ & Kvalitet / livsstadium & $\begin{array}{l}\text { Höjd över snö- } \\
\text { täcket }(m)\end{array}$ & Riktning & Position \\
\hline Rovsundet & 17.3 & With canopy & $4.45-6.30$ & $\mathrm{~S}$ & Not exposed \\
\hline Rovsundet & 14.2 & Dead trunk & $3.15-4.75$ & $\mathrm{~S}$ & Not exposed \\
\hline Rovsundet & 14.6 & With canopy & $6.40-6.80$ & SW & Not exposed \\
\hline Rovsundet & 7.2 & With canopy & $2.25-2.60$ & SE & Not exposed \\
\hline Rovsundet & 11.2 & With canopy & $2.55-3.10$ & $\mathrm{~S}$ & Not exposed \\
\hline Rovsundet & 10.8 & With canopy & $4.15-5.50$ & $\mathrm{~S}$ & Not exposed \\
\hline Rovsundet & 16.2 & With canopy & $9.55-9.90$ & $\mathrm{~S}$ & Not exposed \\
\hline Rovsundet & 21.2 & With canopy & $7.35-7.60$ & SW & Not exposed \\
\hline Rovsundet & 15.3 & Dead trunk & $8.60-9.25$ & $\mathrm{~S}$ & Not exposed \\
\hline Rovsundet & 14.4 & Dead trunk & $2.00-2.50$ & SW & Not exposed \\
\hline Rovsundet & 15.4 & Dead trunk & $\begin{array}{l}3.00-3.10 \\
3.50-3.65\end{array}$ & $\mathrm{~S}$ & Not exposed \\
\hline Rovsundet & 10.9 & Dead trunk & $\begin{array}{l}1.50-1.80 \\
2.00-2.10\end{array}$ & $\mathrm{~S}$ & Not exposed \\
\hline Rovsundet & 10.9 & Dead trunk & $2.05-2.15$ & SE & Not exposed \\
\hline Tavlefjärden & 23.2 & Dead trunk & $4.80-7.55$ & SE & Not exposed \\
\hline Hedmansgrundet & 18.2 & With canopy & $7.40-9.70$ & SW & Not exposed \\
\hline Hedmansgrundet & 16.7 & Dead trunk & $8.80-10.15$ & $E$ & Not exposed \\
\hline Tavlefjärden & 17.3 & With canopy & $5.70-5.90$ & $\mathrm{~S}$ & Exposed \\
\hline Tidesviken & 7.7 & Dead trunk & $1.30-1.75$ & SE & Exposed \\
\hline Rovsundet & 19.2 & With canopy & $6.30-6.70$ & SE & Exposed \\
\hline Tidesviken & 14.3 & Dead trunk & $2.90-3.15$ & SW & Not exposed \\
\hline Hedmansgrundet & 11.4 & Dead trunk & $\begin{array}{l}1.55-1.80 \\
2.05-2.15\end{array}$ & W & Not exposed \\
\hline Hedmansgrundet & 18.2 & With canopy & $7.40-7.95$ & SW & Not exposed \\
\hline Tavlefjärden & 14.4 & With canopy & $4.40-4.95$ & SE & Not exposed \\
\hline Tidesviken & 15.9 & Dead trunk & $6.20-6.45$ & SW & Exposed \\
\hline
\end{tabular}




\section{Appendix 2. Summary data on weather and foraging intensity of Black Woodpeckers Dryocopus martius on grey alders Alnus incana}

\begin{tabular}{|c|c|c|c|c|c|c|c|c|}
\hline \multirow[b]{2}{*}{$\begin{array}{l}\text { Time period } \\
\text { Tidsperiod }\end{array}$} & \multirow[b]{2}{*}{$\begin{array}{l}\text { Census } \\
\text { date } \\
\text { Inventerings- } \\
\text { dag }\end{array}$} & \multirow[b]{2}{*}{$\begin{array}{l}\text { Average tem- } \\
\text { perature }\left({ }^{\circ} \mathrm{C}\right) \\
\text { Medel- } \\
\text { temperatur }\left({ }^{\circ} \mathrm{C}\right)\end{array}$} & \multicolumn{3}{|c|}{$\begin{array}{l}\text { Snow depth }(\mathrm{cm}) \\
\text { Snödjup }(\mathrm{cm})\end{array}$} & \multirow[b]{2}{*}{$\begin{array}{l}\mathrm{N} \text { trees } \\
\text { Antal träd }\end{array}$} & \multicolumn{2}{|c|}{$\begin{array}{l}\text { Litter dry weight (g) } \\
\quad \text { Flistorrvikt (g) }\end{array}$} \\
\hline & & & $\begin{array}{l}\text { start of } \\
\text { week } \\
\text { veckans } \\
\text { början }\end{array}$ & $\begin{array}{l}\text { end of } \\
\text { week } \\
\text { veckans } \\
\text { slut }\end{array}$ & $\begin{array}{l}\text { weekly } \\
\text { average } \\
\text { vecko- } \\
\text { medelvärde }\end{array}$ & & $\begin{array}{l}\text { total } \\
\text { totalt }\end{array}$ & $\begin{array}{l}\text { average } \\
\text { per tree } \\
\text { medel per } \\
\text { träd }\end{array}$ \\
\hline 29 Nov-5 Dec & $6 \mathrm{Dec}$ & -4.3 & NA & 9 & 9.0 & 6 & 1357.6 & 226 \\
\hline $6 \mathrm{Dec}-12 \mathrm{Dec}$ & $13 \mathrm{Dec}$ & -2.0 & 9 & 13 & 11.0 & 4 & 557.3 & 139 \\
\hline 13 Dec-19 Dec & $20 \mathrm{Dec}$ & 0.4 & 13 & 10 & 11.5 & 7 & 995.6 & 142 \\
\hline 20 Dec-26 Dec & $27 \mathrm{Dec}$ & -9.4 & 10 & 0 & 5.0 & 3 & 279.2 & 93 \\
\hline 27 Dec-2 Jan & 3 Jan & -1.0 & 0 & 7 & 3.5 & 4 & 431.7 & 108 \\
\hline 3 Jan-9 Jan & 10 Jan & -3.0 & 7 & 0 & 3.5 & 1 & 118.3 & 118 \\
\hline 10 Jan-16 Jan & $17 \mathrm{Jan}$ & -1.9 & 0 & 28 & 14.0 & 16 & $\begin{array}{r}2000-3000 \\
\text { (estimation) }\end{array}$ & $\begin{array}{l}125- \\
188\end{array}$ \\
\hline 17 Jan-23 Jan & 24 Jan & -1.6 & 28 & 5 & 16.5 & 3 & 293.8 & 98 \\
\hline 24 Jan-30 Jan & 31 Jan & -6.6 & 5 & 5 & 5.0 & 3 & 371.7 & 124 \\
\hline 31 Jan-6 Feb & 7 Feb & -0.1 & 5 & 6 & 5.5 & 2 & 80 & 40 \\
\hline 7 Feb-13 Feb & 14 Feb & -0.6 & 6 & 3 & 4.5 & 1 & 428.9 & 429 \\
\hline 14 Feb-20 Feb & 21 Feb & -3.1 & 3 & 23 & 13.0 & 1 & 39.8 & 40 \\
\hline 21 Feb-27 Feb & 28 Feb & -7.0 & 23 & 33 & 28.0 & 2 & 96 & 48 \\
\hline 28 Feb-6 Mar & $7 \mathrm{Mar}$ & -5.0 & 33 & 33 & 33.0 & 3 & 687.9 & 229 \\
\hline
\end{tabular}

